\title{
Resistance of Wild and Near Isogenic Bean Lines with Arcelin Variants to Zabrotes subfasciatus (Boheman). I - Winter Crop
}

\author{
Fernando M. Lara ${ }^{1}$ \\ ${ }^{1}$ Departamento de Entomologia e Nematologia, FCAV/UNESP, Rodovia \\ Carlos Tonanni, km 5, 14870-000, Jaboticabal, SP. \\ An. Soc. Entomol. Brasil 26(3): 551-560 (1997) \\ Resistência a Zabrotes subfasciatus (Boheman) em Genótipos de Feijoeiro \\ Portadores de Arcelina nas Sementes. I - Plantio de Inverno
}

RESUMO - Verificou-se a resistência de linhagens de feijoeiro (Phaseolus vulgaris) portadoras de arcelina nas sementes e provenientes de plantio de inverno, a Zabrotes subfasciatus (Boheman) (Coleoptera: Bruchidae). Foram conduzidos dois ensaios em laboratório, sem e com chance de escolha, com os genótipos: Arc. 1, Arc. 2, Arc. 3, Arc. 4, (linhagens quase-isogênicas contendo arcelina 1, 2, 3 e 4, respectivamente); Arc. 1S, Arc. 3S, Arc. 5S (linhagens selvagens contendo arcelina 1, 3 e 5, respectivamente); IAPAR MD-808 e Porrillo 70. Utilizaram-se parcelas com $10 \mathrm{~g}$ de cada linhagem e a proporção de 7 casais adultos/parcela. Observaram-se a atratividade, a oviposição, a emergência e o peso de adultos, a mortalidade, o período de desenvolvimento e a perda de peso das sementes. Constatou-se a não-preferência do inseto (atração e oviposição) somente para os genótipos Arc. 3S e Arc. 5S. Os genótipos selvagens Arc. 5S e Arc. $1 \mathrm{~S}$ e as linhagens quase-isogênicas Arc. 1 e Arc. 2, apresentaram alta resistência (antibiose) a Z. subfasciatus; as linhagens Arc. 4 e Arc. 3 apresentaram resistência moderada, provavelmente devido a não-preferência para alimentação.

PALAVRAS-CHAVE: Insecta, Phaseolus vulgaris, antixenose, preferência, antibiose.

ABSTRACT - The objective of this study was to determine the resistance of winter crops of bean (Phaseolus vulgaris) lines with arcelin variants to Zabrotes subfasciatus (Boheman) (Coleoptera: Bruchidae). Two trials, a no-choice test and a free-choice test, were set up under laboratory conditions using genotypes Arc. 1, Arc. 2, Arc. 3 and Arc. 4 (near isogenic lines containing arcelin 1, 2, 3 and 4, respectively), genotypes Arc. 1S, Arc. 3S and Arc. 5S (wild lines containing arcelin 1, 3 and 5, respectively), and genotypes IAPAR MD-808 and Porrillo 70. Plots with $10 \mathrm{~g}$ of each line and a proportion of 7 adult pairs/plot were used. Attractiveness, oviposition, emergence and adult weight, mortality, developmental period, and seed weight loss were determined. Nonpreference (attraction and oviposition) was observed only for the wild genotypes Arc. 3S and Arc. 5S. The wild genotypes Arc. 5S and Arc. 1S and the near isogenic lines Arc. 1 and Arc. 2 presented high resistance of the antibiosis type to $Z$. subfasciatus. Arc. 4 and Arc. 3 presented moderate resistance, probably due to feeding nonpreference.

KEY WORDS: Insecta, Phaseolus vulgaris, antixenosis, preference, antibiosis. 
Brazilian bean production is markedly reduced during storage due to the attack by insects, in particular Zabrotes subfasciatus (Boheman), which is considered to be the most harmful species (Rossetto 1966). This species is being controlled with insecticides which involve costs and cause problems of residues when insecticides are applied shortly before consumption. Thus, the study and implementation of other control methods is necessary, particularly the use of resistant genotypes (Lara 1991).

Many studies have been conducted to obtain bean lines resistant to pests that attack stored grains (Pábon et al. 1976; Oliveira et al. 1979; Schoonhoven et al. 1983; Rêgo et al. 1986; Decheco et al. 1986, Mendes et al. 1995; Oriani et al. 1996).

Excellent perspectives have recently arisen with the discovery of a new protein, called arcelin, found in wild beans in 1986 by Dr. J.R. Andreas in a study carried out at the University of Wisconsin, U.S. Researchers at this University and at CIAT observed that arcelin blocks the insect's digestion and has no toxic effect on humans (Walter 1992). Several studies have been conducted on these arcelin-containing wild genotypes and on several bred lines, confirming resistance or susceptibility as a function of the arcelin variants present and determining the types of resistance involved (Cardona et al. 1989, Minney et al. 1990, Dobie et al. 1990, Posso et al. 1992, Ishimoto \& Kitamura 1993). In Brazil, in studies on improved materials (near isogenic lines) containing arcelin, Pereira et al. (1995) observed that lines with Arc. 1 and Arc. 2 were more resistant when compared to lines containing Arc. 3 and Arc. 4 and to arcelin-free varieties after 150 days of storage under conditions of natural infestation (free-choice situation).

The objective of the present study was to determine the resistance of winter crops of wild and near isogenic bean genotypes containing arcelin in the seeds to Z. subfasciatus and the mechanisms involved.

\section{Material and Methods}

The genotypes were planted on May 23, 1995 in an area of the Teaching and Research Farm of FCAV-UNESP, Jaboticabal campus, in randomized blocks with five replications using normally recommended culture and fertilizing conditions. The materials containing arcelin were obtained from the CNPAF/ EMBRAPA. After harvesting, the seeds were placed in clear glass containers and stored in a refrigerator at $2 \pm 3^{\circ} \mathrm{C}$ to eliminate possible latent infections. During the trials, the materials were kept in a BOD at a constant temperature of $27^{\circ} \mathrm{C}$ and $70 \%$ air $\mathrm{RH}$. The insects used were from an artificially reared colony maintained on IAC-carioca cultivar. All trials were carried out in the Laboratories of Host Plant Resistance to Insects, Department of Entomology and Nematology, FCAV/UNESP.

No-Choice Test. The following materials were used: Arc. 1, Arc. 2, Arc. 3, and Arc. 4 (genotypes bred by EMBRAPA containing arcelin 1, 2, 3, and 4, respectively); Arc. 1S, Arc. 3S, and Arc. 5S (wild genotypes containing arcelin 1, 3 and 5, respectively); IAPAR MD-808 (resistant to mosaic and susceptible to bean weevil), and Porrillo 70 (without arcelin and susceptible to bean weevil). Ten $g$ of each genotype were placed in plastic boxes and the study was carried out in a completely randomized design with 6 replications. Seven pairs of newly emerged (0-24 hours) Z. subfasciatus were confined to these boxes according to the method of Schoonhoven \& Cardona (1982) for a period of 7 days. A few days after this operation, hatched, unhatched and total egg numbers were counted. After the beginning of the formation of emergence "windows", the boxes were observed daily and emerged male and female adults were removed and weighted.

The data were used to calculate mean developmental time (from egg to adult) of males and females, percent hatched eggs and larval+pupal mortality rate (ratio of number of emerged individuals to number of hatched eggs). Mean dry seed weight loss caused by 
bean weevil was also calculated. The data were submitted to analysis of variance by the $\mathrm{F}$ test and the means were compared by the Tukey test. When necessary, the original data were transformed to $\mathrm{x}^{1 / 2}$ or $(\mathrm{x}+0,5)^{1 / 2}$.

Free-Choice Test. The test was conducted on genotypes Arc. 1, Arc. 2, Arc. 3, Arc. 4, Arc. 3S, Arc. 5S, IAPAR MD-808 and Porrillo 70 according to the method described earlier, except that the boxes with the genotypes were placed on circular arenas containing a styrofoam disk with peripheral openings for box insertion. Each arena represented a block with all genotypes. A total of 56 pairs of $Z$. subfasciatus were released inside the arena, the containers were closed individually 24 hours later and insects were removed and counted 6 days later. The trial was carried out with 6 replications.

\section{Results and Discussion}

No-Choice Test. There was no significant difference among treatments in terms of total number of eggs (Table 1). The lowest number and percentage of hatched eggs (70.6\%) were observed in Arc. 4, followed by Porrillo 70 (75.9\%). Few adults emerged from Arc. 5S and Arc. 1S, followed by Arc. 1 and Arc. 2 (Fig. 1). The remaining genotypes presented data significantly similar to those for susceptible controls. These results are related to those of larval+pupal mortality rates, which were low (11.4\%) in Arc. 3S and high (more than $70 \%$ ) in Arc. 5S, Arc. 1S, Arc. 1 and Arc. 2, with emphasis on an $87.7 \%$ rate in Arc. 5S. The low mortality observed in Arc. 3S (as well as in bred Arc. 3) suggests that antibiosis does not occur in materials with this type of arcelin. The data in this figure also show that there were no genotype effects on sex ratio, which was approximately $1: 1$.

The period of male insect development (Table 2) was prolonged by almost $50 \%$ when the insects fed on genotypes Arc. 1S and Arc. 5S (more than 52 days) compared to MD-808 and Porrillo 70 (32 to 33 days). The male cycle was also prolonged in near isogenic lines. The cycle observed in Arc. 3S was similar to those for the susceptible controls, confirming the previously discussed absence of antibio-

Table 1. Mean $( \pm$ SE) number of eggs and hatched eggs laid by Zabrotes subfasciatus on bean seeds from winter crops (no-choice test). ${ }^{1}$

\begin{tabular}{|c|c|c|c|}
\hline \multirow[t]{2}{*}{ Genotypes } & \multicolumn{2}{|c|}{ Number of eggs } & \multirow[t]{2}{*}{ Hatched eggs (\%) } \\
\hline & Total & Hatched & \\
\hline Arc. 1 & $232.2 \pm 14.8$ & $192.2 \pm 17.7 \mathrm{abc}$ & 82.3 \\
\hline Arc. 2 & $246.2 \pm 8.7$ & $201.5 \pm 12.2 \mathrm{ab}$ & 81.8 \\
\hline Arc. 3 & $231.2 \pm 10.7$ & $185.2 \pm 12.8 \mathrm{abc}$ & 80.1 \\
\hline Arc. 4 & $213.0 \pm 10.0$ & $150.3 \pm 13.3 \mathrm{c}$ & 70.6 \\
\hline Arc. 1S & $240.3 \pm 4.2$ & $212.5 \pm 3.9 \mathrm{a}$ & 88.4 \\
\hline Arc. $3 \mathrm{~S}$ & $219.2 \pm 9.8$ & $195.0 \pm 10.7 \mathrm{abc}$ & 89.0 \\
\hline Arc. 5S & $216.8 \pm 9.0$ & $201.5 \pm 8.3 \mathrm{ab}$ & 92.9 \\
\hline IAPAR MD-808 & $212.5 \pm 8.9$ & $166.5 \pm 13.1 \mathrm{abc}$ & 78.4 \\
\hline Porrillo 70 & $212.2 \pm 10.4$ & $161.0 \pm 8.9 \mathrm{bc}$ & 75.9 \\
\hline$\overline{\mathrm{F}}$ & 1.86 n.s. & $4.58 *$ & \\
\hline $\mathrm{CV}(\%)$ & 5.17 & 6.74 & \\
\hline
\end{tabular}

${ }^{1}$ Original data (duly transformed for analysis); means followed by the same letters do not differ using Tukey test $(\mathrm{P}<0.05)$. 


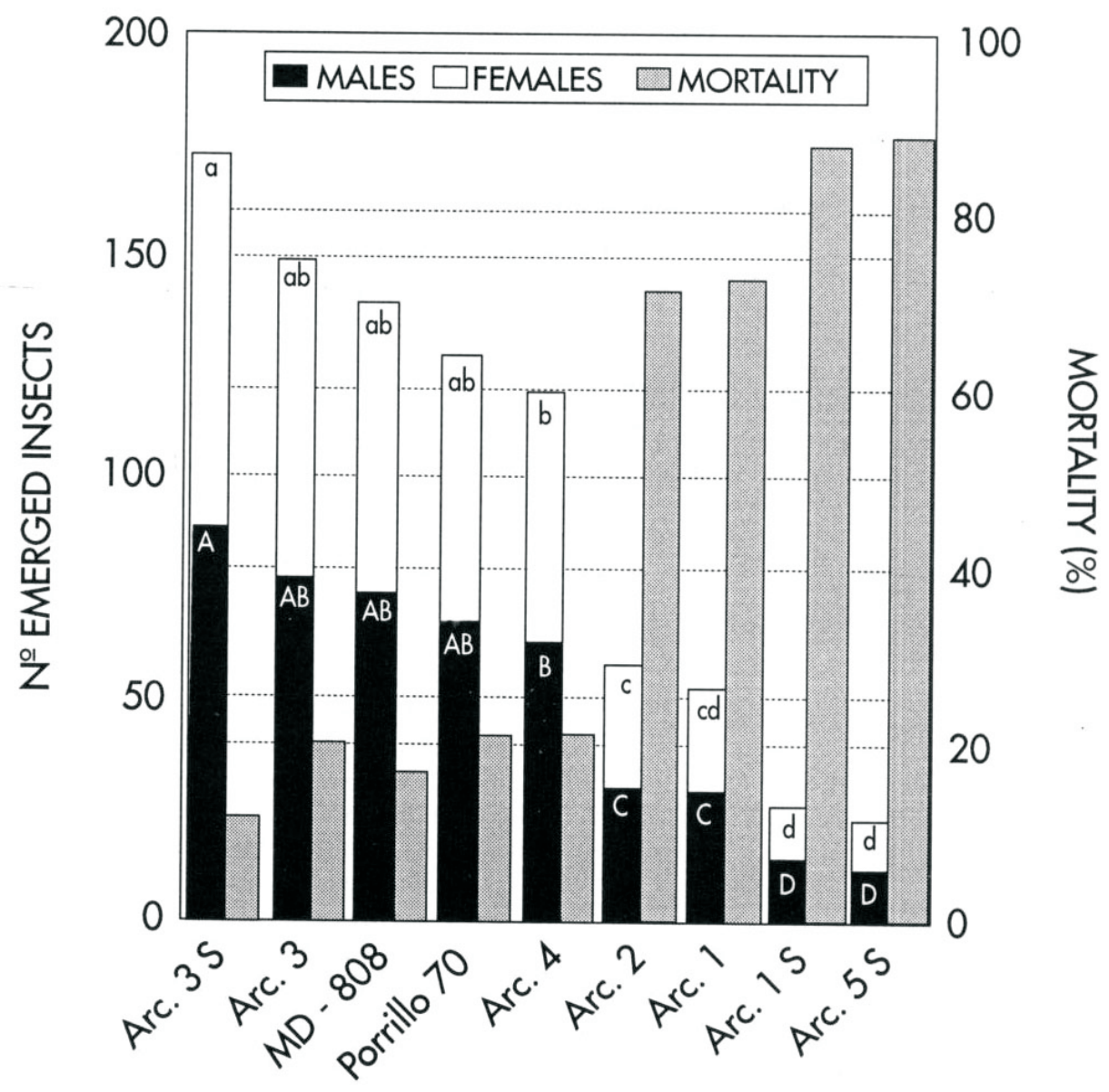

GENOTYPES

Figure 1. Mean number of Zabrotes subfasciatus adults emerged from winter crop bean seeds and mortality rate of larvae+pupae (no-choice test).

sis in this material. Similar results were observed for the female cycle. Although the mortality observed in Arc. 4 was low (Fig. 1), this material affected insect development by delaying its cycle, suggesting resistance of the feeding nonpreference type.

Adult insect weight (Table 2) of both males and females was negatively affected by feeding on some genotypes, especially Arc. 5S, Arc. $1 \mathrm{~S}$ and Arc. 1. Both males and females from Arc. $5 \mathrm{~S}$ presented a weight reduction of $40 \%$ compared to insects from MD-808. Insect weight was also reduced, though to a lesser extent, in Arc. 3 and Arc. 4, suggesting the occurrence of feeding nonpreference in these genotypes.

Arc. 3S and Arc. 3 presented the highest seed weight losses, followed by the susceptible materials. Arc. $1 \mathrm{~S}$ and Arc. 5S, followed by Arc. 1 and Arc. 2, were the least damaged 
Table 2. Mean ( \pm SE) developmental time (egg to adult) and weight of Zabrotes subfasciatus feeding on bean seeds from winter crops (no-choice test). ${ }^{1}$

\begin{tabular}{llllll}
\hline \multirow{2}{*}{ Genotypes } & \multicolumn{2}{c}{ Period (days) } & & \multicolumn{2}{c}{ Weight $(\mathrm{mg})$} \\
\cline { 2 - 3 } \cline { 5 - 6 } & Male & Female & & Male & Female \\
\hline Arc. 1 & $45.6 \mathrm{~b}$ & $45.3 \mathrm{~b}$ & & $0.57 \mathrm{de}$ & $1.01 \mathrm{f}$ \\
& $( \pm 0.6)$ & $( \pm 0.6)$ & & $( \pm 0.02)$ & $( \pm 0.04)$ \\
Arc. 2 & $38.3 \mathrm{c}$ & $38.4 \mathrm{~d}$ & & $0.80 \mathrm{abc}$ & $1.40 \mathrm{bc}$ \\
& $( \pm 0.3)$ & $( \pm 0.4)$ & & $( \pm 0.01)$ & $( \pm 0.03)$ \\
Arc. 3 & $41.1 \mathrm{c}$ & $42.3 \mathrm{c}$ & & $0.67 \mathrm{bcd}$ & $1.19 \mathrm{de}$ \\
& $( \pm 0.3)$ & $( \pm 0.3)$ & & $( \pm 0.02)$ & $( \pm 0.02)$ \\
Arc. 4 & $42.1 \mathrm{bc}$ & $43.7 \mathrm{bc}$ & & $0.65 \mathrm{~cd}$ & $1.17 \mathrm{e}$ \\
& $( \pm 0.5)$ & $( \pm 0.4)$ & & $( \pm 0.0)$ & $( \pm 0.01)$ \\
Arc. 1S & $55.0 \mathrm{a}$ & $53.8 \mathrm{a}$ & & $0.60 \mathrm{de}$ & $1.00 \mathrm{f}$ \\
& $( \pm 1.4)$ & $( \pm 0.4)$ & & $( \pm 0.02)$ & $( \pm 0.02)$ \\
Arc. 3S & $33.2 \mathrm{~d}$ & $33.3 \mathrm{e}$ & & $0.77 \mathrm{abc}$ & $1.31 \mathrm{~cd}$ \\
& $( \pm 0.2)$ & $( \pm 0.1)$ & & $( \pm 0.01)$ & $( \pm 0.01)$ \\
Arc. 5S & $52.5 \mathrm{a}$ & $54.1 \mathrm{a}$ & & $0.50 \mathrm{e}$ & $0.92 \mathrm{f}$ \\
& $( \pm 1.7)$ & $( \pm 1.4)$ & & $( \pm 0.01)$ & $( \pm 0.05)$ \\
IAPAR MD-808 & $32.4 \mathrm{~d}$ & $32.7 \mathrm{e}$ & & $0.84 \mathrm{a}$ & $1.53 \mathrm{a}$ \\
& $( \pm 0.1)$ & $( \pm 0.2)$ & & $( \pm 0.01)$ & $( \pm 0.03)$ \\
Porrillo 70 & $33.1 \mathrm{~d}$ & $33.5 \mathrm{e}$ & & $0.80 \mathrm{ab}$ & $1.47 \mathrm{ab}$ \\
& $( \pm 0.2)$ & $( \pm 0.2)$ & & $( \pm 0.01)$ & $( \pm 0.03)$ \\
\hline F & $102.65^{*}$ & $224.10^{*}$ & $14.59 *$ & $64.52^{*}$ \\
CV (\%) & 4.85 & 3.23 & 10.96 & 5.48 \\
\hline
\end{tabular}

${ }^{1}$ Original data (duly transformed for analysis); means followed by the same letters do not differ using Tukey test $(\mathrm{P}<0.05)$.

(Fig. 2).

Free-Choice Test. Analysis of the total number of individuals attracted to each material under study shows that all genotypes were less preferred by the insects compared to the two susceptible lines IAPAR MD-808 and Porrillo 70. The wild lines Arc. 3S and Arc. 5S were the least preferred of all (Fig. 3), with percentages of insects ranging from 13 to $18 \%$ of those observed in MD-808. In the near isogenic lines, these percentages ranged from 33 to $54 \%$. The nonpreference of the insects for Arc. 3S, in addition to the probable effect on their feeding, as previously discussed, explains why this line is considered resistant by several authors.

The two wild genotypes were the least preferred also in terms of oviposition (Table 3 ), differing significantly from the two controls. The near isogenic lines were in an intermediate position and did not differ from the controls or the wild lines. Oviposition was obviously related to the number of insects that went to each genotypes. These results show that, under free-choice conditions involving several genotypes, the insect manifests its preference (attraction/oviposition), whereas in no-choice tests this does not occur. Percentage of hatched eggs ranged from 65.2 to $84.4 \%$, with the lowest rates observed for the controls and Arc. 4.

The largest number of emerged adults (total) occurred in MD-808 (Fig. 4) and the smallest occurred in Arc. 5S, which, although being a very low value (3.2), did not differ 


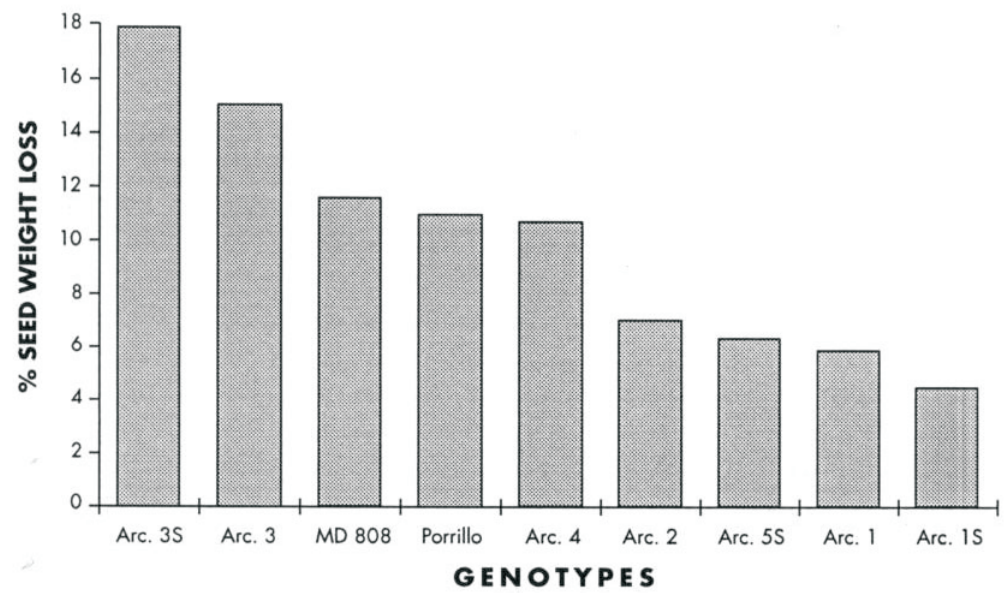

Figure 2. Mean percent dry weight loss of winter crop bean seeds after attack by Zabrotes subfasciatus (no-choice test).

significantly from Arc. 2 (26.8), Arc. 1 (33.3), lowed by Arc. 2 (82.6\%) and Arc. 1 (77.0\%). Arc. 3S (45.6) and Arc. 4 (79.5). The mortal- The mortality rates observed in the remainity rate was highest in Arc. 5S (93.0\%), fol- ing genotypes were similar to those observed

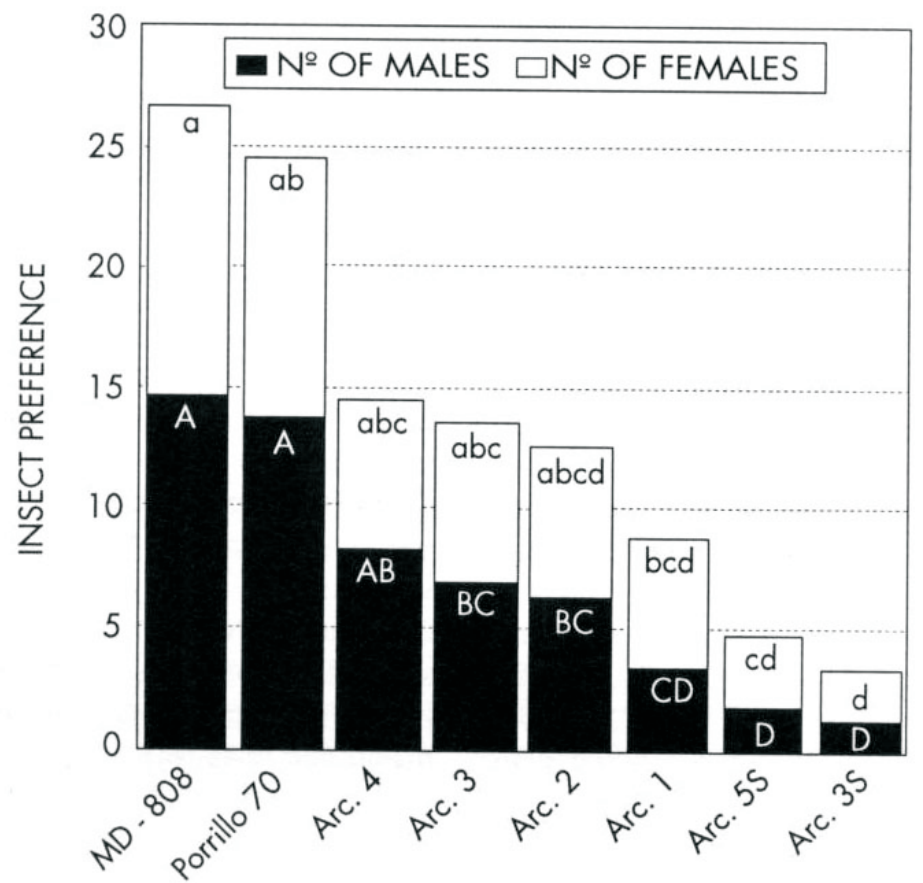

Figure 3. Preference of Zabrotes subfasciatus adults for winter crop bean seeds (freechoice test). 
Table 3. Mean $( \pm \mathrm{SE})$ number of eggs and hatched eggs laid by Zabrotes subfasciatus on bean seeds from winter crops (free-choice test). ${ }^{1}$

\begin{tabular}{lrrrr}
\hline Genotypes & \multicolumn{3}{c}{ Number of eggs } & \multirow{2}{*}{ Hatched eggs (\%) } \\
\cline { 2 - 3 } & \multicolumn{2}{c}{ Total } & \multicolumn{1}{c}{ Hatched } & \\
\hline Arc. 1 & $184.8 \pm 59.1 \mathrm{ab}$ & $144.7 \pm 45.2 \mathrm{ab}$ & 78.3 \\
Arc. 2 & $210.7 \pm 40.2 \mathrm{ab}$ & $154.0 \pm 28.2 \mathrm{ab}$ & 73.1 \\
Arc. 3 & $192.3 \pm 11.9 \mathrm{ab}$ & $142.0 \pm 14.9 \mathrm{ab}$ & 73.8 \\
Arc. 4 & $202.8 \pm 62.6 \mathrm{ab}$ & $136.7 \pm 35.5 \mathrm{ab}$ & 67.8 \\
Arc. 3S & $69.4 \pm 31.5 \mathrm{~b}$ & $58.6 \pm 29.7 \mathrm{~b}$ & 84.4 \\
Arc. 5S & $58.2 \pm 5.2 \mathrm{~b}$ & $45.5 \pm 4.6 \mathrm{~b}$ & 78.2 \\
IAPAR MD-808 & $310.2 \pm 40.7 \mathrm{a}$ & $215.3 \pm 27.5 \mathrm{a}$ & 69.4 \\
Porrillo 70 & $305.5 \pm 45.6 \mathrm{a}$ & $199.2 \pm 31.8 \mathrm{a}$ & 65.2 \\
\hline F & $5.79 *$ & $4.79 *$ & \\
CV $(\%)$ & 28.47 & 28.56 & \\
\hline
\end{tabular}

${ }^{1}$ Original data (duly transformed for analysis); means followed by the same letters do not differ using Tukey test $(\mathrm{P}<0.05)$.

in the controls, except for Arc. 3S, which showed the lowest mortality rate $(22.2 \%)$, again excluding the possibility of antibiosis being related to arcelin 3 .

The period of insect development (Table

4) was much longer in Arc. 5S (58.0 days for

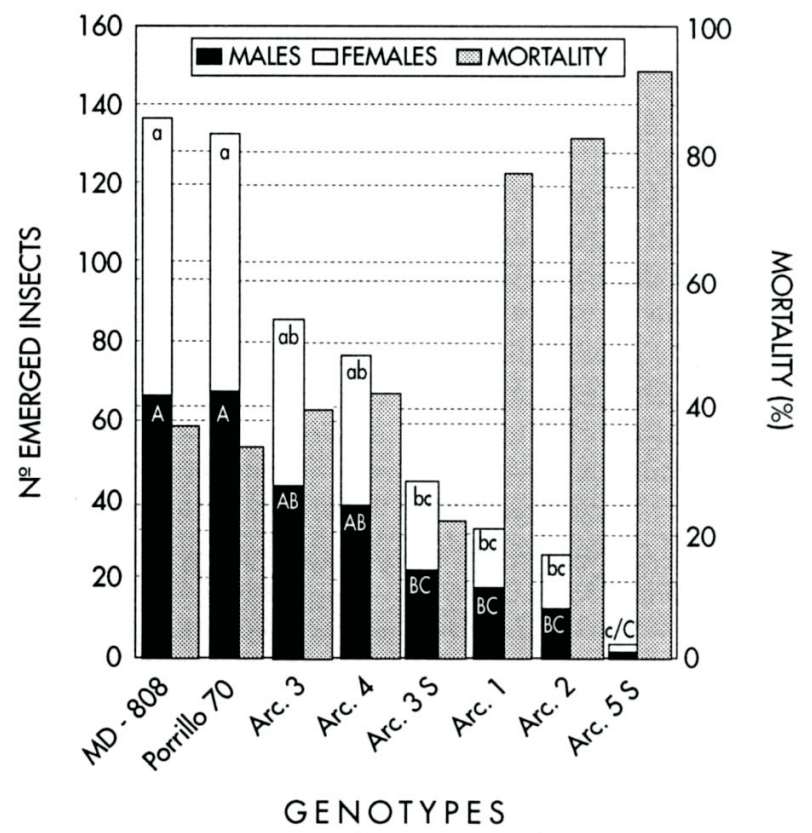

Figure 4. Mean number of Zabrotes subfasciatus adults emerged from winter crop bean seeds and mortality rate of larvae+pupae (free-choice test). 
Table 4. Mean ( \pm SE) developmental time (egg to adult) and weight of Zabrotes subfasciatus feeding on bean seeds from winter crops (free-choice test). ${ }^{1}$

\begin{tabular}{|c|c|c|c|c|}
\hline \multirow[t]{2}{*}{ Genotypes } & \multicolumn{2}{|c|}{ Period (days) } & \multicolumn{2}{|c|}{ Weight (mg) } \\
\hline & Male & Female & Male & Female \\
\hline Arc. 1 & $\begin{array}{l}46.1 \mathrm{~b} \\
( \pm 0.9)\end{array}$ & $\begin{array}{l}49.2 \mathrm{~b} \\
( \pm 1.4)\end{array}$ & $\begin{array}{l}0.68 \text { de } \\
( \pm 0.05)\end{array}$ & $\begin{array}{l}1.06 \text { bc } \\
( \pm 0.09)\end{array}$ \\
\hline Arc. 2 & $\begin{array}{l}38.3 \mathrm{~cd} \\
( \pm 0.9)\end{array}$ & $\begin{array}{l}40.1 \mathrm{~cd} \\
( \pm 0.5)\end{array}$ & $\begin{array}{l}0.80 \mathrm{bc} \\
( \pm 0.02)\end{array}$ & $\begin{array}{l}1.49 \mathrm{ab} \\
( \pm 0.02)\end{array}$ \\
\hline Arc. 3 & $\begin{array}{l}43.0 \mathrm{bc} \\
( \pm 0.4)\end{array}$ & $\begin{array}{l}43.8 \mathrm{bc} \\
( \pm 0.3)\end{array}$ & $\begin{array}{l}0.73 \mathrm{bcd} \\
( \pm 0.01)\end{array}$ & $\begin{array}{l}1.32 \mathrm{abc} \\
( \pm 0.03)\end{array}$ \\
\hline Arc. 4 & $\begin{array}{l}44.1 \mathrm{~b} \\
( \pm 0.4)\end{array}$ & $\begin{array}{l}44.5 \mathrm{bc} \\
( \pm 0.3)\end{array}$ & $\begin{array}{l}0.71 \text { cde } \\
( \pm 0.02)\end{array}$ & $\begin{array}{l}1.32 \mathrm{abc} \\
( \pm 0.04)\end{array}$ \\
\hline Arc. 3S & $\begin{array}{l}34.5 \mathrm{~d} \\
( \pm 1.0)\end{array}$ & $\begin{array}{l}34.6 \mathrm{~d} \\
( \pm 1.4)\end{array}$ & $\begin{array}{l}0.79 \mathrm{bcd} \\
( \pm 0.02)\end{array}$ & $\begin{array}{l}1.30 \mathrm{abc} \\
( \pm 0.03)\end{array}$ \\
\hline Arc. 5S & $\begin{array}{l}58.0 \mathrm{a} \\
( \pm 4.0)\end{array}$ & $\begin{array}{l}61.0 \mathrm{a} \\
( \pm 0.4)\end{array}$ & $\begin{array}{l}0.59 \mathrm{e} \\
( \pm 0.03)\end{array}$ & $\begin{array}{l}1.05 \mathrm{c} \\
( \pm 0.13)\end{array}$ \\
\hline IAPAR MD-808 & $\begin{array}{l}33.3 \mathrm{~d} \\
( \pm 0.2)\end{array}$ & $\begin{array}{l}33.6 \mathrm{~d} \\
( \pm 0.1)\end{array}$ & $\begin{array}{l}0.94 \mathrm{a} \\
( \pm 0.03)\end{array}$ & $\begin{array}{l}1.57 \mathrm{a} \\
( \pm 0.15)\end{array}$ \\
\hline Porrillo 70 & $\begin{array}{l}34.1 \mathrm{~d} \\
( \pm 0.6)\end{array}$ & $\begin{array}{l}34.4 \mathrm{~d} \\
( \pm 0.4)\end{array}$ & $\begin{array}{l}0.84 \mathrm{ab} \\
( \pm 0.01)\end{array}$ & $\begin{array}{l}1.63 \mathrm{a} \\
( \pm 0.06)\end{array}$ \\
\hline $\bar{F}$ & $42.73 *$ & $31.27 *$ & $14.91 *$ & $7.44 *$ \\
\hline $\mathrm{CV}(\%)$ & 6.77 & 9.44 & 8.23 & 14.58 \\
\hline
\end{tabular}

${ }^{1}$ Original data (duly transformed for analysis); means followed by the same letters do not differ using Tukey test $(\mathrm{P}<0.05)$.

males and 61.0 for females), followed by Arc. 1, Arc. 4, Arc. 3 and Arc. 2. In Arc. 3S this period was similar to those observed for the controls, which ranged from 33 to 34 days. Concerning insect weight, the males with lowest weight were those from Arc. $5 \mathrm{~S}(0.59 \mathrm{mg})$ and Arc. 1 (0.68 mg), and those from MD808 and Porrillo 70 had the highest weights (0.94 and $0.84 \mathrm{mg}$, respectively). It should be pointed out that the weight of adults from wild and bred materials differed significantly from that of MD-808. The heaviest females also came from the controls and the lightest came from Arc. 5S and Arc. 1, as also noted for the males.

Seed weight loss (Fig. 5) in this type of trial reflects the loss that would occur during storage of these materials in the same place after one generation of insect attack. It can be seen that the least damaged genotypes were Arc. 5S, Arc. 1 and Arc. 2. Arc. 4, Arc. 3S and Arc. 3 were in an intermediate position and the controls showed the highest losses.

General analysis of the data shows that nonpreference (attraction and oviposition) occurred only in genotypes Arc. 3S and Arc. 5S. On the basis of the other data, especially mortality rate, period of development and adult weight at emergence, the wild genotypes Arc. 5S and Arc. 1S and the near isogenic lines Arc. 1 and Arc. 2 presented high resistance to $Z$. subfasciatus of the antibiosis type since they caused high larval+pupal mortality. Lines Arc. 4 and Arc. 3 presented moderate resistance probably due to feeding nonpreference. These results agree with those reported by Pereira et al. (1995) and Wanderley et al. (1997) who noted a high degree of resistance in lines Arc. 


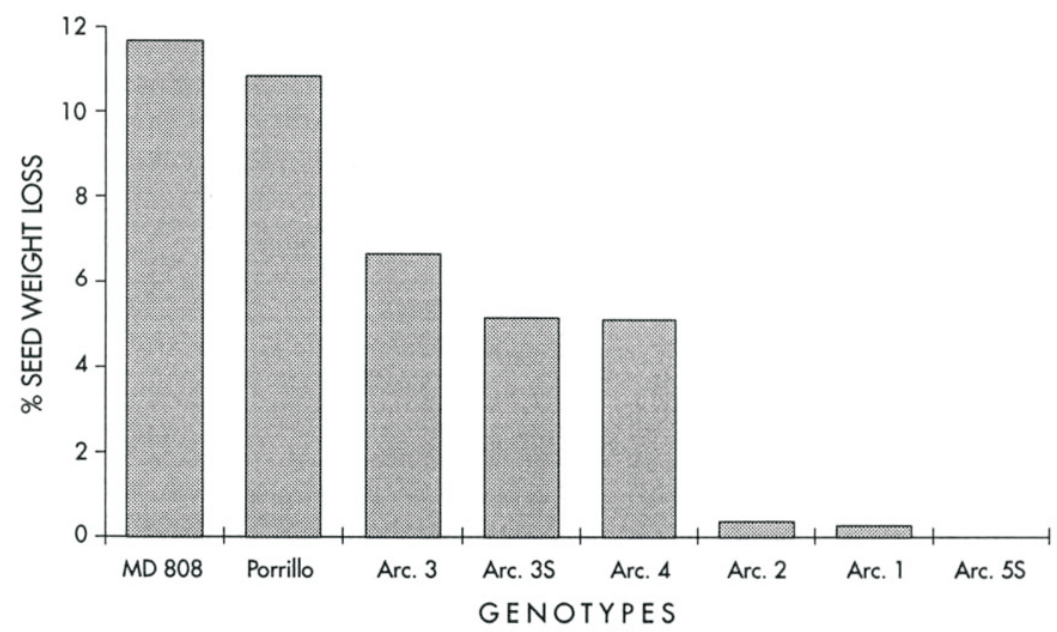

Figure 5. Mean percent dry weight loss of winter crop bean seeds after attack by Zabrotes subfasciatus (free-choice test).

1 and Arc. 2, followed by Arc. 3 and Arc. 4.

\section{Acknowledgments}

The author is grateful to Conselho Nacional de Desenvolvimento Científico e Tecnológico $(\mathrm{CNPq})$ for a research fellowship and to EMBRAPA, which provided the seeds.

\section{References Cited}

Cardona, C., C.E. Posso, J. Kornegay, J. Valor \& M. Serrano. 1989. Antibiosis effects of wild dry bean accessions on the mexican bean weevil and the bean weevil (Coleoptera:Bruchidae). J. Econ. Entomol. 82: 310-315.

Decheco, A., B. Moncada, \& M. Ortiz. 1986. Desarrollo de Zabrotes subfaciatus sobre seis variedades de frijol en Lima. Rev. Per. Entomol. 29: 77-79.

Dobie, P., J. Dendy, C. Sherman, J. Padgham, A. Wood \& A.M.R. Gatehouse. 1990. New sources of resistance to Acantoscelides obtectus (Say) and Zabrotes subfasciatus
Boheman (Coleoptera: Bruchidae) in mature seeds of five species of Phaseolus. J. Stored Prod. Res. 26: 177-186.

Ishimoto M. \& K. Kitamura. 1993. Specific inhibitory activity and inheritance of an $\alpha$-amylase inhibitor in a wild bean accession resistant to the mexican bean weevil. Jap. J. Breed. 43: 69-73.

Lara, F.M. 1991. Princípios de resistência de plantas a insetos. $2^{\mathrm{a}}$ ed., SãoPaulo, Icone, 336p.

Mendes, M.A.S., J.N.L. Fonseca \& M.R. de O. Vilarinhos. 1995. Resistência da semente de Phaseolus vulgaris ao caruncho Acanthoscelides obtectus (Coleoptera: Bruchidae). Pesq. Agropec. Bras. 30: 893-897.

Minney, B.H.P., A.M.R. Getehouse, P. Dobie, J. Dendy, C. Cardona \& J.A. Gatehouse. 1990. Biochemical bases of seed resistance to Zabrotes subfasciatus (bean weevil) in Phaseolus vulgaris (Common Bean), a mechanism of arcelin toxicity. J. Ins. Physiol. 36: 757-767. 
Oliveira, A.M., B.E. Pacova, S. Sudo, A.C.M. Rocha \& D.F. Barcellos. 1979. Incidência de Zabrotes subfasciatus Boheman, 1833 e Acanthoscelides obtectus Say, 1831 em diversos cultivares de feijão armazenado (Coleoptera, Bruchidae). An. Soc. Entomol. Brasil 8: 47-35.

Oriani, M.A. de G., F.M. Lara \& A.L. Boiça Junior. 1996. Resistência de genótipos de feijoeiro a Zabrotes subfasciatus (Boh.) (Col. Bruchidae). An. Soc. Entomol. Brasil 25: 213-216.

Pábon, I.A.R., C.J. Aguirre \& J.A.Q. Reyes. 1976. Resistência de diez y siete variedades comerciales de frijol (Phaseolus vulgaris L.) en almacenamiento, al ataque de gorgojo pintado de los granos (Zabrotes subfasciatus Boh.). Acta Agron. 26:3948.

Pereira, P.A.A., M. Yokoyama, E.D. Quintela \& F.A. Bliss. 1995. Controle do caruncho Zabrotes subfasciatus (Boheman, 1833) (Coleoptera Bruchidae) pelo uso de proteína da semente em linhagens quase-isogênicas do feijoeiro. Pesq. Agropec. Bras. 30: 1031-1034.

Posso, C.E., C. Cardona, J.F. Valor \& H. Morales. 1992. Development of lines of beans resistant to the weevil Zabrotes subfasciatus (Boh.) (Coleoptera: Bruchidae). Rev. Colomb. Entomol. 18: 8-13.
Rêgo, A.F.M., A.F.S.L. Veiga, Z.A. Rodriguez, M.L. Oliveira \& D.V. Reis. 1986. Efeito da incidência de Zabrotes subfasciatus (Boheman, 1833) (Coleoptera, Bruchidae) sobre genótipos de Phaseolus vulgaris L. An. Soc. Entomol. Brasil 15: 53-69.

Rossetto, C.J. 1966. Sugestões para armazenamento de grãos no Brasil. O Agronômico 18: 38-51.

Schoonhoven, A. Van \& C. Cardona. 1982. Low levels of resistance to the mexican bean weevil in dry beans. J. Econ. Entomol. 75: 567-569.

Schoonhoven, A. Van, C. Cardona \& J. Valor. 1983. Resistance to the bean weevil and the mexican bean weevil (Coleoptera, Bruchidae) in noncultivated common bean acessions. J. Econ. Entomol. 76: 1255-1259.

Walter, A. 1992. Un frijol silvestre protege los cultivos sin plaguicidas. CIAT International 11: 3-4.

Wanderley, V.S., J.V. Oliveira \& M.L. Andrade Jr. 1997. Resistência de cultivares e linhagens de Phaseolus vulgaris L. a Zabrotes subfasciatus (Boh.) (Coleoptera: Bruchidae). An. Soc. Entomol. Brasil 26: 315-320.

Received 06/I/97. Accepted 29/X/97. 